\title{
Proving and improving
}

\author{
Gerald Grace's model for evaluation of \\ Catholic schools - a practitioner \\ perspective from Ireland
}

\section{Marie Griffin}

\section{Introduction: The current Irish context}

In Ireland, because of the historical position of the Catholic Church, the majority of schools at both primary and second levels were established and run by Religious Congregations and the local bishops. Article 42 of the Irish Constitution emphasises the right of parents to educate their children according to their conscience and goes on to state that 'parents shall be free to provide this education in their homes or in private schools or in schools recognised or established by the State' (McDonagh, 2019, p. 9). While primary schools are still approximately $89 \%$ in Catholic patronage, Catholic second-level schools now just account for just under half of all schools. In the year 2018-2019, the number of primary schools under Catholic patronage fell slightly $(0.4 \%)$ while there was an increase of nearly $5 \%$ in the number of multi-denominational primary schools. There was growth at all levels in the second-level schools because of a population bulge but greater growth in the number of pupils in multi-denominational schools $(4 \%)$ than in Catholic schools $(1 \%)$ (DES, 2020).

It has been the policy of the Department of Education and Skills over the past ten years to introduce more diversity into the education system to reflect a changing demographic in a growing population and more people identifying as being of no faith in censuses (in 2016, 10\% identified as having 'no religion' compared to $6 \%$ in 2011. $78 \%$ of people identified as Catholic compared to $84 \%$ in $2011^{2}$ ). The Minister for Education noted in 2019 that the changes were part of the implementation underway 'to provide for greater diversity and choice in the Irish education system' (DES, 2019). As Grace (2002) points out, this choice for parents is not between ideology and ideology-free schools. 'Secularism has its own ideological assumptions about the human person, the ideal society, the ideal system of schooling and the meaning of human existence' (p. 14). O'Sullivan (2006) notes that the State's role under the mercantile paradigm for education involves 'managing both the demands of the various interest groups in the marketplace of education and the educational process itself' (p. 120). Over the past decade, interest groups seeking nonfaith schools have made increased demands on the Department of Education and this has driven the agenda for change as much as

DOI: $10.4324 / 978100317 \mid 553-20$ 
the changing demographic itself. ${ }^{3}$ The demands of interest groups and the response of both the State and the Catholic Church constitutes the only public debate on the nature and values of education since the Forum on Patronage and Pluralism in the primary sector (2012). ${ }^{4}$ A key proposal of the Forum was to divest the ownership of religious schools in 28 areas to multi-denominational patrons.

Catholic bishops recognise the need for more diversity in the Irish primary school system and a small number of schools have so far been divested to the State. The Church's co-operation is not just for pragmatic reasons; it also advocated for freedom from coercion as well as freedom for religious belief, practice and proclamation. Furthermore, it is not only Irish society that is changing; the Church has changed as well (Conway, 2017). However, local parents do not want change because they are, by and large, very happy with their children's education in the local Catholic school. In one area of Dublin, where the Archdiocese sought to divest one of many Catholic schools in a parish, parents warned of another 'Brexit type disaster' if the Catholic patronage was changed:

In the case of St Oliver Plunkett's School in Malahide, the parents' association warned that the loss of the school's religious ethos could lead to the cancellation of nativity plays and carol services, and would impact on the "spirit, culture and even the name of the school".

(Irish Times, 5 April 2019)

\section{School evaluation in Ireland}

While a large percentage of schools are under the patronage of the Catholic Church, these schools, like all schools in the Republic of Ireland, are regulated by the State through the Department of Education and Skills (DES). Every school has its own ethos or 'characteristic spirit' as outlined in the Education Act (1998), 'determined by the cultural, educational, moral, religious, social, linguistic and spiritual values and traditions which inform and are characteristic of the objectives and conduct of the school' (section 2 (b)). The Board of Management has a responsibility to ensure that the ethos is maintained. Catholic schools, while reflecting their local communities, are challenged to give expression to their characteristic spirit through the lens of Catholic faith and to allow the Catholic faith to inform the values and traditions that are lived out and nurtured on a daily basis in the school.

The DES strictly regulates the curriculum of schools on advice from the National Council for Curriculum and Assessment and through the inspectorate's evaluation and inspection processes. Grace (2015) terms the measures of secular performance and compliance with education laws and regulations Performative Secular Evaluation (PSEV). It is 'the evaluation of an institution'. Whole-school inspections were only introduced into second-level schools and formalised in a process for all schools in Ireland in 2004. Like almost all inspectorates, Irish 
school inspectors fulfil an accountability function, inspecting and reporting on the work of schools and the effectiveness of school leaders, evaluating the 'institution' but they have no remit in evaluating the effectiveness of the school ethos. There may be some reference to ethos in the published evaluation report but in terms of inclusion and student care only:

The school is very inclusive in keeping with the ethos of the Sisters of Mercy.... Care for students is of a very high standard.

(Scoil Bhríde, Tuam)

Support for students with Special Educational Needs (SEN) is good. The school has a very inclusive ethos.

(St Joseph’s, Rush)

There is no reference to school ethos in the Chief Inspector's most recent report (2018).

\section{Mission Catholic Evaluation}

The concept of evaluation specific to Catholic schools has long been accepted as a practice in the UK where, under legislation, the governors of faith schools must obtain a separate inspection of 'denominational Religious Education and collective worship, 5 This inspection must be carried out by an inspector appointed by the bishop under the Education Act (2005) (www.legislation.gov. uk/ukpga/2005/18/section/5, accessed 8 December 2020). While this practice is well established in UK schools, it is an unknown concept in Ireland. Canon Law assigns the role of the oversight of religious education to the local bishop (Code of Canon Law \#801-806). Irish bishops appoint Diocesan Advisors to visit schools on their behalf but recent research has highlighted a lack of clarity in relation to their role generally and also in relation to any evaluative function (McCormack, 2021).

In that sense, Professor Grace was prophetic in 2015 in urging self-evaluation of what he terms Mission Catholic Evaluation (MCEV) in Irish schools. His address raised the question of why Catholic schools need to examine their Catholic identity in practice and so prevent what Grace terms mission drift; 'the generally unintended drift from mission commitments over time, as a result of complex factors including social and political pressures and weak school leadership' (2015, CEIST conference address). However, the importance of the evaluation of the catholicity of schools is assuming greater importance, not least because of the changing population demographic. Professor Grace notes that the:

...prime focus of MCEV is concerned with a larger perspective related to issues such as the vitality of Catholicity and spirituality in the school, its mission integrity, its distinctive mode of leadership, the extent to which 
Catholic Religious and Social Teaching is part of its educational programme and how its overall culture and ethos facilitates a process of integral formation for its students and not just a process of training. It is an evaluation of a distinctive mission.

(2015, CEIST conference address)

In 2002, Grace said that 'one of the prime purposes of the Catholic school and perhaps its fundamental rationale is to keep alive and to renew the culture of the sacred in a profane and secular world' (p. 5).

In his address to CEIST schools, drawing on the research of Potterton and Northmore in South Africa (2014), ${ }^{6}$ Gerald Grace promoted the idea of colleague-implemented school evaluation, using colleagues such as recently retired Catholic teachers and principals as external examiners. This self-evaluation would have to operate the same standards of impartiality and objectivity used by the State inspectorate. Grace acknowledged, however, that these colleague professionals would possess the added advantage of a good understanding of what constitutes a Catholic education mission. This type of evaluation, he proposed, was far more desirable and effective than State-mandated school inspection alone. Catholic schools could then publish a combination of PSEV and MCEV as a measure of their effectiveness as Catholic schools. While there are obviously resource implications, financially challenged schools could seek funding from Trusts or diocesan sources. What is necessary is a model of these evaluations that give some real and practical indication of the schools' catholicity.

Grace recognised the need for such a model in his address to CEIST and even suggested a schema as one possible template for the process. He refers to this as the Vitality and Spirituality in the School (VSC). To determine the standard for the evaluation, Grace draws on the publication from the Congregation for Catholic Education (1977), The Catholic School, and notes that the first priority criterion in any evaluation exercise is contained in the two paragraphs, 'Christ is the foundation of the whole educational enterprise in a Catholic school' (par. 34), and 'Mindful of the fact that man has been redeemed by Christ, the Catholic schools aims at forming in the Christian those particular virtues which will enable him to live a new life in Christ' (par. 36).

In the Irish context, the Catholic Schools Partnership ${ }^{7}$ in Ireland has articulated the following similar vision for Catholic schools:

Catholic schools in Ireland are a living expression of a long and varied tradition of education inspired by the life of Christ as lived in the Church. Such schools emphasise the dignity of the human person as a child of God called to work with other persons in creating an inclusive community in service of the common good; where knowledge is sought and respected while faith is nurtured and challenged. 
As well as the VSC, Grace posits the Vocation and Formation criterion (VFC). Education in a Catholic school is not a training for life but is part of a larger process of formation: a holistic tradition that looks to nourish young people in all aspects of their lives. Education, under this criterion, is not just a means to a 'good job', important as that is, but to a development of a vocation of service to others. In other words, Catholic schools should work on the formula that the development of talent and commitment to the common good is both good citizenship and good for people.

The question then is how these aims are to be recognised and assessed in a Catholic school. Grace proposes, under the VSC, certain basic elements such as a prescribed time for RE, the services of a Chaplain in secondary schools and the presence of the local clergy at primary level, regular celebration of the sacraments and the preparation of students for the same. A sacred space in the schools such as a prayer room is important as are the opportunities for retreats for students and staff. The teachings of Jesus Christ would also permeate other aspects of the curriculum as the occasion arises, and not just in RE. Grace gives no indication how the VFC might be measured in the Catholic school but does reference Catholic social teaching and the vibrancy of such teaching and activity might be such a measure.

Grace's model presents a very possible option for Irish Catholic schools. CEIST and other Trust bodies visit their schools annually and report on the provision of RE, school retreats, sacred spaces etc. While the bishops appoint Diocesan Advisors to visit schools and support RE teachers, these Diocesan Advisors have no clear role in evaluating the catholicity of the schools (McCormack, 2021). If these different groups, or the colleague professionals, were to use a common template, such as that proposed by Grace to be then reported by the school and to a central Catholic agency, the nature of catholicity in Irish schools could be charted.

Rather than promote Grace's model in CEIST schools in 2015, CEIST disseminated an approach that was developed by the central body, the Catholic Schools Partnership (CSP). In 2016, after a national consultation process, CSP initiated a process for second-level schools: Understanding and Living the Ethos in a Catholic Voluntary Secondary School. ${ }^{8}$ This process was carried out entirely within the school community so that it would be characterised by honesty and open dialogue. It also sought to eschew the bureaucracy and mechanism of more formal processes. It was to be a shared reflection by trustees, staff, students, parents, members of the Board of Management and the broader school community about the nature of the school ethos. The emphasis was on the founding intention of the school and an exploration of how this founding intention was finding contemporary expression in the school mission. The process was intended to be 'life-giving and supportive' and was described as a series of conversations. An outline of activity for three years was given where the school selected targets for attention in the context of living out its founding intention. While the CSP process was very valuable, and was 
developed following a pilot programme, very few schools engaged with the whole programme for a number of reasons. New curriculum initiatives were introduced by the Department of Education at that time and there was some consequent industrial action. It was a clear example of PSEV taking precedence over MCEV. There was also no accountability to any Church organisation, nor to CEIST, for failure to engage in the process.

Also in 2016, following a national consultation process, the Catholic Education Services Committee (CESC) established a working group to develop a strategic plan to bring greater cohesion between Catholic patronage/trusteeship and management at second level in the Republic of Ireland. This plan was put into effect in November 2020 and presages a new robustness of the Catholicsector response to education matters. The Catholic Education Partnership is the new company charged with oversight and coordination of patronage and management of second-level schools. Through new governance arrangements, there is now greater cohesion that would allow for a more robust response in terms of determining the catholicity of schools.

Another lesson from the earlier CSP process was that support needs to be provided to schools for assistance but also to ensure that it takes place at all. This support and impetus could well be Grace's colleague professionals in association with the Trust bodies and the Diocesan Advisors. Support from outside, coordinated at diocesan level also demonstrates in a tangible way that this process has capital and credibility. When this support was given in a pilot programme at primary level, engagement was much higher and more effective. ${ }^{10}$ Training would be integral, and clarity would also be necessary on the measures or instruments to be used and the outcome of the evaluations. The central focus of MCEV, according to Grace, would be mission integrity, or assessment of how the school is living out its characteristic spirit. The challenges in avoiding mission drift are social and political pressures and weak school leadership.

While school leaders are evaluated in their leadership and management of the institution, there is no evaluation of their leadership of the mission. Grace (2015) outlines how school leaders have been transformed into some form of Directors of educational corporations in a manner that is alien to the leadership of Catholic tradition and practice. He notes that research surrounding the concept of servant leadership and the presence of spiritual capital are what make effective faith leaders. Grace (2002) defines spiritual capital as 'resources of faith and values derived from commitment to a religious tradition and possessed by persons who do not act simply as professionals but as professionals and witnesses' (p. 236). He adds these Catholic leaders have 'the animating spiritual capital of Catholic schooling'. They also have a commitment to Catholic social teaching.

Primary teachers in Catholic schools in Ireland were traditionally trained in Catholic teacher training colleges but these colleges are themselves more diverse now and many trainee teachers are 'unchurched'. The Church is chiefly 
dependent on teachers to carry out the mission of the Catholic Church to meet the challenges of a modern and secular culture as enunciated in Gravissimum Educationis (1965). At primary and second level, there is little training available for leaders in faith schools. ${ }^{11}$ Such training is not a prerequisite for appointment to leadership in a Catholic school and no specific training is required on appointment. Some questions on commitment to ethos are asked at interview but there is ad hoc ethos support following appointment. The Alliance for Catholic Education (ACE) programme from Notre Dame University (USA) is currently working with some school leaders at primary level in Ireland and has also run ethos courses for CEIST teachers and principals but these programmes are not part of an integral faith nourishment programme at national level. A mission renewal for teachers and leaders in Catholic schools will be another challenge for the new Catholic structures in Ireland.

\section{The value of Mission Catholic Evaluation (MCEV) for Catholic schools?}

If a Catholic school is to stay true to its characteristic spirit as outlined in the Irish Education Act (1998) and to outline its mission (as required under Charities regulation), ${ }^{12}$ then it must have some measure of its effectiveness. There are also other considerations for Irish schools that necessitate their being able to define themselves in a tangible and robust fashion for parents and the wider public but also for the school community itself. With the change in the application process for patronage of new schools, prospective patrons must now outline the nature and ethos of their school to local parents who then declare a choice to DES. The process presents challenges to prospective Catholic patrons who are unaccustomed to 'selling their wares'. To date, most patronage applications have been won by multi-denominational patrons (www.education.ie/en/ Press-Events/Press-Releases/2020-press-releases/PR20-11-12-1.html, accessed 5 December 2020).

Because of the hegemony of the Catholic school structures at primary level mainly, the 2018 Education (Admissions to Schools) Act now prohibits Catholic schools from giving preference to pupils from Catholic families. The so-called baptism barrier (www.irishtimes.com/opinion/we-need-secular-primary-school s-to-reflect-changes-in-religious-practice-1.2147029, accessed 10 December 2020) highlighted in a small number of oversubscribed schools was a local response to oversubscription. The problem has not been resolved by the legislative change, however, as the schools remain oversubscribed. These changes have taken place with little evidence of exclusive practices in Catholic schools. A single ten-yearold statistic from a 2007 DES audit of enrolment practices which claimed that selection criteria applied to $20 \%$ of children seeking enrolment was cited as one of the reasons for initiating the change (Clegg 2019).

This same report found that Catholic schools had more than their proportional share of children from minority, new Irish, special needs and 
disadvantaged backgrounds (DES, 2007). These schools are fulfilling their mission for the poor and the marginalised and giving contemporary expression to their founding intention but there was no centralised Catholic data or entity to defend the Church schools' position. While DES can report on the number of schools and pupils, Catholic schools themselves have no general data on categories of students and admissions, still less on the value of initiatives and practices. In such circumstances, it is almost impossible to respond to popular criticism or inform public opinion. Consistent and standardised data on school mission self-evaluation, using Grace's model, would be a powerful tool in defending Catholic schools in the public space.

\section{Catholic school research in Ireland}

Gerald Grace devoted much of his later career to disseminating research on Catholic schooling through the journal he edited, International Studies in Catholic Education (ISCE). In 2002, Grace anticipated that Ireland would become a major source of research studies in the areas of foundation, preferential option for the poor and school effectiveness. It is not apparent that this is the case. Certainly, there have been only ten articles from Irish writers since Grace established ISCE in 2009. Perhaps because of the dominant position of Catholic schools in Irish society, there has never been a need for research on the nature or effects of Catholic schools per se as most schools, were, in fact Catholic and any research therefore related to them. This has left a lacuna in terms of data about Catholic schools. Catholic colleges in Ireland, as in the UK, have historically focused on teacher training (like the UK in the past) rather than research, but this is now changing. There are two welcome developments. First, the foundation of the Mater Dei Centre for Catholic Education within the Institute of Education in Dublin City University is a welcome development in terms of research on Catholic schooling. Second, the Irish Institute for Catholic Studies in Mary Immaculate College, Limerick is a cross-faculty, interdisciplinary, research-oriented and community engaged network of scholars involved in the study of Catholicism and its contribution to culture and society in Ireland and beyond.

\section{Conclusion}

In 2015, Gerald Grace proposed a model of mission self-evaluation for CEIST schools in Ireland. The model was prophetic if slightly premature. A similar model addressing the need for a focus on catholicity was presented to Irish schools in 2016 by CSP, which was disseminated to all Catholic second-level schools. This latter model wasn't particularly successful because the performative agenda took precedence, there was no support offered to schools and there was no sense of accountability to Church authorities. The need for the evaluation was also perhaps not as apparent as now. 
Today there are growing challenges for Catholic schools from the changing demographic and the State agenda. There is a paramount need for the Catholic sector to speak with a unified voice and to have the data with which to defend Catholic schools. The central voice is now being coordinated by the Catholic Education Partnership and there is an acknowledgement that nourishment of ethos in schools will need support. In the years since his address to CEIST, the time is more opportune for Grace's model of self-evaluation in Catholic schools to be used. We have the way, and now the will is greater.

\section{Notes}

1 CEIST is a lay Catholic trust organisation set up in 2007 by five Religious Congregations to assume patronage (and ownership) of their second-level schools into the future. CEIST has 107 non-fee-paying second-level schools across Ireland. There are nearly 60,000 second-level pupils in CEIST schools, about $16 \%$ of the national total.

2 www.cso.ie/en/releasesandpublications/ep/p-cp8iter/p8iter/p8rrc/

3 For example, see the Equate education campaign. www.digitalcharitylab.org/2016/02/ equate-a-new-irish-campaign-for-education-equality/, accessed 12 December 2020.

4 The Forum on Patronage and Pluralism in the Primary sector arose from the 2011 Programme for Government and constituted a time-limited forum to 'allow all stakeholders, including parents, to engage in an open debate on change of patronage in communities where it is appropriate and necessary'. Four hundred and thirty-four submissions were received and a Forum Report (2012), with recommendations, was published.

5 John Viner: 'When inspection is not by Ofsted'. https://blog.optimus-education.com/ when-inspection-not-ofsted, accessed December 52020.

6 Potterton and Northmore (2014). Improving Schools through Evaluation: The Experience of Catholic Schools in South Africa.

7 The Catholic Schools Partnership (CSP) is an association established by the Irish Bishops' Conference and the Conference of Religious of Ireland. It was formally launched in 2010. It aims, inter alia, to:

- Foster coherence in Catholic education at national level

- Provide a unified voice for Catholic education in the public forum and with educational bodies and the Government.

- Support Catholic educators in the core activities of learning and teaching in order to foster high-quality lifelong learning and faith development for all learners.

8 An explanatory booklet and DVD was distributed, through the patron, to every Catholic voluntary secondary school in the country.

9 The Catholic Education Services Committee (CESC) is composed of bishops, members of the Association of Missionaries and the Religious of Ireland, a nominee of the third-level Catholic colleges and two nominees of the Catholic Education Trust companies that are public juridic persons.

10 The Catholic Schools Partnership appointed a Research Assistant to engage with schools in the local Diocese to spearhead the ethos initiative at primary level. The first iteration of this approach took place in the Diocese of Kilmore but has since been replicated in Elphin, Wexford and parts of Dublin. The Diocesan Education Offices were also involved in supporting the initiative. 
11 Masters and postgraduate programmes for leaders in Catholic schools are provided by Mary Immaculate College and the Marino Institute. Some of the Catholic Trust bodies also provide less formal training for such leadership.

12 All schools are registered charities and must submit an annual account of their activities to the Charities Regulatory Authority, www.charitiesregulator.ie/en/ information-for-charities/annual-reporting

\section{References}

Catholic Schools Partnership (CSP). (2015). Catholic Primary Schools in a Changing Ireland Sharing Good Practice on Inclusion of All Pupils. Maynooth: Catholic Schools Partnership.

Catholic Schools Partnership (CSP). (2016). Understanding and Living the Ethos in a Catholic Voluntary Secondary School: A Process Centred on Conversations. Dublin: Veritas.

Clegg, M. C. (2019). Policy and Partnership, Studies, 108 (429), pp. 30-31.

Conway, E. (2017). Why Faith Schools Matter and the Challenge of Divestment, The Furrow, 68 (6), pp. 350-361.

Department of Education and Skills (DES). (2007). Inclusion of Students with Special Educational Needs: Post-Primary Guidelines. www.education.ie/en/Publications/InspectionReports-Publications/Evaluation-Reports-Guidelines/insp_inclusion_students_sp_ed_nee ds_pp_guidelines_pdf.pdf, accessed 13 May 2021.

Department of Education and Skills (DES). (2018). Chief Inspector's Report: January 2013-July 2016. Dublin: Inspectorate.

Department of Education and Skills (DES). (2019). www.education.ie/en/Press-Events/ Press-Releases/2019-press-releases/PR19-12-23.html, accessed 10 December 2020.

Department of Education and Skills (DES). (2020). www.education.ie/en/Publications/Sta tistics/Statistical-Reports/statistical-bulletin-2020-overview-of-education-1999-2019. pdf, accessed 12 December 2020.

Forum on Patronage and Pluralism in the Primary Sector. (2012). Report of the Forum's Advisory Group. www.education.ie/en/Press-Events/Events/Patronage-and-Pluralism -in-the-Primary-Sector/The-Forum-on-Patronage-and-Pluralism-in-the-Primary-SectorReport-of-the-Forums-Advisory-Group.pdf, accessed 13 May 2021.

Grace, G. (2002). Catholic Schools: Mission, Markets and Morality. London: RoutledgeFalmer.

Grace, G. (2015). Catholic Schools Self Evaluation: Five International Challenges. Address to CEIST Conference, Athlone, 24 September 2015.

Gravissimum Educationis, in Abbott, W. (Ed.) (1966). The Documents of Vatican II. New York: Herder and Herder.

McDonagh, F. (2019). What Constitutes a Catholic School in 2019? A Legal Perspective, Studies, 108 (429), pp. 8-19.

McCormack, C. (2021). Using Visible or Invisible Maps? A Case Study of the Role of the Diocesan Advisor. Unpublished PhD thesis, Dublin City University.

O'Sullivan, D. (2006). Cultural Politics and Irish Education since the 1950s: Policy, Paradigms and Power. Dublin: Institute of Public Administration.

Potterton, M. and Northmore, C. (2014). Improving Schools Through Evaluation: The Experience of Catholic Schools in South Africa, International Studies in Catholic Education, 6 (2), pp. 178-190. 